\title{
Et ikke fullt så mildt hjerneinfarkt
}

\author{
Et vanlig argument mot å gi trombolytisk behandling intravenøst til pasienter med milde symptomer ved akutt \\ hjerneinfarkt er at disse pasientene uansett har god prognose. Milde symptomer etterfølges av et mildt for- \\ løp. En slik logikk finner imidlertid ikke støtte i forskning.
}

Rekanaliserende trombolytisk behandling intravenøst er assosiert med større sjanse for fordelaktig prognose ved akutt hjerneinfarkt. Den iskemiske skaden kan begrenses hvis blodproppen løser seg opp i tide. Hjerneinfarkt med milde symptomer er en vanlig problemstilling i akuttmottaket. Milde symptomer blir ofte definert som en lav skår på National Institutes of Health Stroke Scale (NIHSS) (1). Dette skåringsverktøyet brukes mye ved diagnostikk av hjerneslag og kvantifiserer slagsymptomene fra $0-42$ poeng gjennom målrettet nevrologisk undersøkelse. Et eksempel på milde symptomer kan være en pasient med facialisparese i kombinasjon med lett parese i en arm, som kan gi skår på tre poeng.

Å behandle slike pasienter trombolytisk har vært kontroversielt i fagmiljøene. I nasjonale retningslinjer for trombolyse ved hjerneinfarkt opererer man med «mindre nevrologiske forstyrrelser» som kontraindikasjon for trombolyse (2). Bakgrunnen for dette er at pasienter med milde symptomer ble ekskludert fra de store randomiserte trombolysestudiene, og at noen mener risikoen for hjerneblødning trolig vil overgå den potensielle terapeutiske gevinsten av trombolyse. En slik avveining forutsetter imidlertid at pasienter med hjerneinfarkt og milde akuttsymptomer har et fordelaktig naturlig forløp. Ut i fra det vitenskapelige grunnlaget mener vi det ikke er holdbart å forutsette et slikt forløp.

\section{Dårlig utkomme}

De siste årene har man fått økt evidens for at det naturlige forløpet etter hjerneinfarkt med milde akuttsymptomer ikke er så bra som man trodde $(3,4)$. Blant pasienter uten funksjonshemning som innlegges med milde symptomer eller symptomer i rask bedring, og som ikke får trombolytisk behandling, ender 15-25\% opp med et dårlig utkomme etter tre måneder, definert som alt fra lett funksjonshemning til død (modified Rankin Scale (mRS) 2-6) $(5,6)$. Siden 2006 er alle pasienter med hjerneinfarkt innlagt ved Nevrologisk avdeling, Haukeland universitetssykehus, blitt inkludert i et slagregister (Bergen Stroke

Registry). I denne perioden ble 1149 ikketrombolyserte pasienter med hjerneinfarkt innlagt med lette slagsymptomer (NIHSSskår $<5)$. Alle pasientene var funksjonelt uavhengige og bodde hjemme hos seg selv på forhånd. Ved utreise fra avdelingen hadde $177(15 \%)$ av disse pasientene dårlig utkomme $(\mathrm{mRS}>2)$. I en tidligere publisert artikkel med tall fra registeret, var kun $31 \%$ av de ikke-trombolyserte slagpasientene med milde symptomer initialt, uten symptomer ved utreise (mRS 0) (7).

\section{Forskjellige årsaker}

Det kan være flere grunner til at prognosen ikke er så god som ventet for disse pasientene. En grunn kan være måleinstrumentet, dvs. bruken av National Institutes of Health Stroke Scale til å definere hva som er milde symptomer. National Institutes of Health Stroke Scale er et mye brukt skåringssys-

\section{«Et økende antall}

\section{studier viser at trombo- lytisk behandling ved milde slagtilfeller er gunstig og trygt»}

tem for nevrologiske utfall, men dekker ikke relativt alvorlige symptomer som gangforstyrrelser, håndpareser eller apraksi. I tillegg tas det ikke hensyn til den subjektive funksjonsnedsettelsen som utfallet fører med seg for den enkelte person. En okklusjon i distale del av arteria cerebri media kan for eksempel gi isolert ekspressiv eller impressiv afasi som eneste symptom, og gjøre kommunikasjon svært vanskelig. Dette vil gi en skår på to poeng og dermed karakteriseres som et mildt tilfelle, selv om et slikt symptombilde vil være svært invalidiserende for mange.

En annen årsak til dårlig utkomme kan være at pasientene med milde slagsymptomer får nedsatt funksjon av en annen årsak enn hjerneinfarktet i seg selv, slik som andre sykdommer eller residiv med et mer alvorlig hjerneinfarkt. Dette blir kanskje særlig aktuelt når man vurderer utkomme etter tre måneder, siden mye kan skje i dette tidsrommet som ikke er direkte relatert til det milde hjerneinfarktet i begynnelsen. Dette problemet er imidlertid mindre relevant for pasientene i slagregisteret ved Haukeland universitetssykehus, siden funksjonsnivået ble vurdert ved utreise, dvs. et tidspunkt hvor utkomme er mer direkte relatert til det milde hjerneinfarktet i begynnelsen.

Progresjon av de initialt milde symptomene kan være en tredje forklaring på hvor- for det går dårligere med denne pasientgruppen enn forventet. Dette kan for eksempel skje ved at perfusjonen til det iskemiske området distalt for okklusjonen forverrer seg på bakgrunn av en sviktende kollateralsirkulasjon som initialt var god nok til kun å gi lette slagsymptomer. Biokjemiske prosesser igangsatt av den opprinnelige okklusjonen kan også føre med seg en forverring av symptomene (5).

Uansett hva som ligger bak, er det nokså klart at tankerekken om at milde slagsymptomer automatisk etterfølges av et godt utkomme ikke stemmer med realiteten. Et økende antall studier viser at trombolytisk behandling ved milde slagtilfeller er gunstig og trygt (8-10). Det er usikkert om man vil få randomiserte, kontrollerte studier som kan konkludere på dette emnet, men ut i fra det vi vet i dag, fremstår det som problematisk å avstå fra trombolyse kun basert på argumentet om et godt naturlig forløp hos pasienter med hjerneinfarkt og milde akuttsymptomer.

\section{Christopher Elnan Kvistad \\ echr@helse-bergen.no \\ Nicola Logallo \\ Halvor Næss \\ Lars Thomassen}

Christopher Elnan Kvistad (f. 1982) er lege og stipendiat ved Nevrologisk avdeling, Haukeland universitetssykehus.

Forfatter har fylt ut ICMJE-skjemaet og oppgir ingen interessekonflikter.

Nicola Logallo (f. 1982) er lege i spesialisering ved Nevrologisk avdeling. Haukeland universitetssykehus.

Forfatter har fylt ut ICMJE-skjemaet og oppgir ingen interessekonflikter.

Halvor Næss (f. 1957) er spesialist i nevrologi og i indremedisin. Han er overlege ved Slagenheten, Haukeland universitetssykehus. Forfatter har fylt ut ICMJE-skjemaet og oppgir ingen interessekonflikter.

Lars Thomassen (f. 1947) er spesialist i nevrologi, med spesialkompetanse i nevrovaskulære sykdommer. Han er professor ved Universitetet i Bergen og leder Nevrovaskulær forskningsgruppe.

Forfatter har fylt ut ICMJE-skjemaet og oppgir ingen interessekonflikter. 


\section{Litteratur}

1. National Institutes of Health Stroke Scale (NIHSS). http://nihstrokescale.org/ (24.9.2014).

2. Helsedirektoratet. Nasjonale retningslinjer for behandling og rehabilitering ved hjerneslag 2010. http://helsebiblioteket.no/retningslinjer/ hjerneslag/forord-og-innledning?hideme=true (24.9.2014).

3. Smith EE, Fonarow GC, Reeves MJ et al. Outcomes in mild or rapidly improving stroke not treated with intravenous recombinant tissue-type plasminogen activator: findings from Get With The GuidelinesStroke. Stroke 2011; 42: 3110-5.

4. Balucani C, Levine SR. Mild stroke and rapidly improving symptoms: it's not always a happy ending. Stroke 2011; 42: 3005-7.

5. Coutts SB, Modi J, Patel SK et al. What causes disability after transient ischemic attack and minor stroke?: Results from the CT and MRI in the Triage of TIA and minor Cerebrovascular Events to Identify High Risk Patients (CATCH) Study. Stroke 2012; 43: 3018-22.

6. Nedeltchev K, Schwegler B, Haefeli T et al. Outcome of stroke with mild or rapidly improving symptoms. Stroke 2007; 38: 2531-5.

7. Logallo N, Kvistad CE, Naess H et al. Mild stroke: safety and outcome in patients receiving thrombo lysis. Acta Neurol Scand Suppl 2014: 198: 37-40.

8. Greisenegger S, Seyfang L, Kiechl S et al. Thrombolysis in patients with mild stroke: results from the Austrian Stroke Unit Registry. Stroke 2014; 45: 765-9.

9. Köhrmann M, Nowe T, Huttner HB et al. Safety and outcome after thrombolysis in stroke patients with mild symptoms. Cerebrovasc Dis 2009; 27: 160-6.

10. Willey JZ, Stillman J, Rivolta JA et al. Too good to treat? Outcomes in patients not receiving thrombolysis due to mild deficits or rapidly improving symptoms. Int J Stroke 2012; 7: 202-6.

Mottatt 23.6. 2014, første revisjon innsendt 15.7. 2014, godkjent 22.9.2014. Redaktør: Hanne Støre valeur.

Publisert først på nett. 